\title{
БОТАНІКА
}

УДК 582 (477.84)

doi: $10.25128 / 2078-2357.19 .3 .1$

О. В. ПРИГАРА

Ужгородський національний університет

вул. Українська, 19, Ужгород, 88000

e-mail: pryhara.ov@gmail.com

\section{ЕКОЛОГО-ЦЕНОТИЧНА СТРУКТУРА ФЛОРИ ЗАКАРПАТСЬКОЇ РІВНИНИ}

У статті наведено результати аналізу еколого-ценотичної структури флори Закарпатської рівнини. Згідно зазначеного критерію виділено 7 флороценотипів: неморальнолісовий (Nemoralophyton) - 375 ценоелементів (33,33\% від загальної кількості видів); лучний (Pratophyton) - 220 ценоелементів (18,20\%); лучно-степовий (Prato-Steppophyton) - 179 ценоелементів (14,81\%); ксерочагарниковий (Xerothamnophyton) - 32 ценоелементи $(2,65 \%)$; болотний (Paludophyton) - 47 ценоелементів (3,89\%); гігро-гідрофільний (Hyhro-Hydrophyton) 129 ценоелементів (10,67\%); синантропний (Synantropophyton) - 227 ценоелементів $(18,77 \%)$. Охарактеризовано ценоелементи, які входять до складу виділених типів рослинних угруповань.

Ключові слова: Закарпатська рівнина, флора, тип рослинності, ценоелемент, флороценотип, флороценосвіта.

Закарпатська, або Притисянська, алювіальна рівнина $є$ північно-східною частиною великої Середньо-Дунайської низовини в Закарпатській області. На заході Закарпатська рівнина відокремлена від Середньо-Дунайської низовини зоною розломів по лінії Чоп - Бігань Берегово - Вилок; з північного сходу оточена вулканічним Вигорлат-Гутинським хребтом, який розташований по лінії Ужгород - Хуст. Довжина рівнини 80-90 км, ширина 22-23 км,

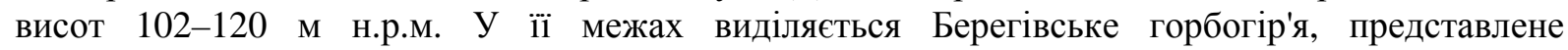
поодинокими куполоподібними вулканічними горами висотою 300-500 м н.р.м. (г. Чорна Гора - 568 м н.р.м., г. Шаланка - 372 м н.р.м. та інші) [12].

Особливості сонячної радіації та атмосферної циркуляції, ландшафтостворювальні фактори, визначили формування на території Закарпатської рівнини помірно-континентального клімату, який характеризується порівняно довгою весною, не особливо спекотним літом, теплою (по відношенню до весни) осінню та порівняно м'якою зимою. Середня кількість опадів коливається від 752 до 1027 мм на рік [2].

Закарпатська рівнина розташована, в основному, на правому березі р. Тиси і це рівнина терасова. На різних терасових рівнях і в різних частинах одних і тих же терас є грунти, у яких поєднуються в різних співвідношеннях буроземний, дерновий процеси, оглеєння та опідзолювання. Грунтоутворюючі породи здебільшого кислі [3].

За фізико-географічним районуванням Закарпатська рівнина розташована в межах Паннонської області та області Закарпатської рівнини фізико-географічної провінції Українських Карпат Карпатської гірської країни [14].

Згідно 3 «Геоботанічним районуванням України» (1977), територія Закарпатської рівнини належить до Надтисянського геоботанічного округу дубових лісів Східнокарпатської гірської 
підпровінції Центральноєвропейської провінції Європейської широколистяної області [4]. Я. П. Дідух та Ю. Р. Шеляг-Сосонко (2003) відносять досліджувану територію до Закарпатського округу скельнодубових та звичайнодубових лісів та остепнених лук Паннонської провінції геліофільних та неморальних лісів, остепнених лук та лучних степів Лісостепової підобласті Євразійської степової області [6].

Метою дослідження є виявлення особливостей еколого-ценотичної структури флори Закарпатської рівнини, встановлення основних закономірностей флорокомплексної диференціації досліджуваного регіону.

\section{Матеріали і методи досліджень}

Залежно від екологічних умов існування та ценотичних взаємовідносин у рослинних угрупованнях, природні види та їх популяції об’єднуються у флористичні комплекси, що виникли в процесі розвитку географічного середовища та еволюції рослинного покриву [7-9]. Належність видів до певних ценоекологічних груп та їх кількісне співвідношення найбільш повно відображають еколого-ценотичні особливості флори та дозволяють простежити ії зв'язки з різними типами рослинності.

В основу еколого-ценотичного аналізу флори Закарпатської рівнини покладено поняття про ценоелемент як узагальнене поняття про представників ценопопуляції конкретного природного виду, які приурочені до рослинних угруповань певного ценотаксону і утворюють флороценотичний комплекс. Згідно з поглядами Р. В. Камеліна [9] та Б. В. Заверухи [8], розподіл ценоелементів флори найбільш чітко вимальовується за основними зональними типами рослинності - флороценотипами, які розглядаються як сукупність флороценоелементів переважно груп формацій тих чи інших типів рослинності, що характеризуються природноісторичними, зональними та еколого-едафічними виділами рослинного покриву досліджуваної території.

Оскільки вказані флороценопи є виділами широкооб'ємними, в їх складі виокремлено флорокомплекси нижчого рангу - флороценосвіти [8], що складаються 3 сукупності флороценоелементів, властивих окремим формаціям чи групам асоціацій.

При вивченні видової різноманітності флори Закарпатської рівнини застосовувався загальноприйнятий морфолого-еколого-географічний метод. При вивченні складу рослинних угруповань використовувались загальноприйняті методики геоботанічних описів [5]. Назви рослин наведені за зведенням S. I. Mosyakin та M. M. Fedoronchuk [16].

\section{Результати досліджень та їх обговорення}

Спонтанна флора Закарпатської рівнини нараховує 1209 видів вищих судинних рослин [11].

Залежно від еколого-ценотичної належності видів до основних типів рослинності, на території досліджуваного регіону виділено 7 флороценотипів: неморальнолісовий (Nemoralophyton), лучний (Pratophyton), лучно-степовий (Prato-Steppophyton), ксерочагарниковий (Xerothamnophyton), болотний (Paludophyton), гігро-гідрофільний (HyhroHydrophyton) та синантропний (Synantropophyton) (табл. 1).

Лісова рослинність, яка була панівною на Закарпатській рівнині в доісторичні часи, у зв'язку з інтенсивним господарським освоєнням території залишилась окремими масивами та представлена, переважно, змішаними звичайнодубовими та скельнодубовими лісами $[10,12$, $15]$.

У складі неморальнолісового флороценотипу виділяються дубово-грабова (Quercetocarpinetophytum), світлодібровна, або геліокверцетальна (Quercetophytum) і фагетальна (Fagetophytum) флороценосвіти.

Флороценосвіта грудової або дубово-грабової рослинності (Querceto-carpinetophytum) нараховує 130 видів (10,75\% від загальної кількості видів флори) і представлена такими ценоелементами: Carpinus betulus L., Quercus petraea (Matt.) Liebl., Populus tremula L., Crataegus monogyna Jacq., Ulmus scabra Mill., Helleborus purpurascens Waldst. Et Kit., Vincetoxicum officinale Moench, Galium vernum L., Milium effusum L., Majanthemum bifolium (L.) F.W.Schmidt, Platanthera chlorantha (Cust) Reichnb., Carex pilosa Scop. Дубово-грабові ліси займають дещо підвищені частини Закарпатської рівнини, які не затоплюються весняними 
водами. Такі ліси є на схилах південних експозицій в околицях міст Ужгород, Мукачево, Виноградово, на схилах вулканічної гори Куклія-Банія поблизу міста Берегово.

Таблиия 1

Еколого-ценотична структура флори Закарпатської рівнини

\begin{tabular}{|c|c|c|c|}
\hline п/п & Флороценотипи та флороценосвіти & $\begin{array}{c}\text { Кількість } \\
\text { видів }\end{array}$ & $\begin{array}{c}\text { Відсоток від } \\
\text { заг. к-сті видів }\end{array}$ \\
\hline 1. & Неморальнолісовий (Nemoralophyton) & 375 & 33,33 \\
\hline & а) дубово-грабова або грудова (Querceto-carpinetophytum) & 130 & 10,75 \\
\hline & б) світлодібровна або геліокверцетальна (Quercetophytum) & 171 & 14,14 \\
\hline & в) букова або фагетальна (Fagetophytum) & 74 & 6,12 \\
\hline 2. & Лучний (Pratophyton) & 220 & 18,19 \\
\hline & а) заплавнолучна (Humidopratophytum) & 97 & 8,02 \\
\hline & б) суходольнолучна (Mesopratophytum) & 123 & 10,17 \\
\hline 3. & Лучно-степовий (Prato-Stepophyton) & 179 & 14,81 \\
\hline 4. & Ксерочагарниковий (Xerothamnophyton) & 32 & 2,65 \\
\hline 5. & Болотний (Paludophyton) & 47 & 3,89 \\
\hline 6. & Гігро-гідрофільна (Hygro-Hydrophyton) & 129 & 10,67 \\
\hline & а) гігрофільна (Hygrophytum) & 79 & 6,53 \\
\hline & б) гідрофільна (Hydrophytum $)$ & 50 & 4,13 \\
\hline 7. & Синантропний (Synantropophyton) & 227 & 18,77 \\
\hline & а) сегетальна (Segetalophytum) & 90 & 7,44 \\
\hline & б) рудеральна (Ruderalophytum) & 137 & 11,33 \\
\hline & Всього видів & 1209 & 100 \\
\hline
\end{tabular}

Геліокверцетальна флороценосвіта (Quercetophytum) нараховує 171 ценоелемент $(14,14 \%$ від загальної кількості видів). Утворена вона світлолюбивими термофільними видами (Quercus robur L., Q. pubescens Willd., Q. cerris L., Q. polycarpa Schur., Tilia argentea Desf. Et DC., T. tomentosa Mill., Fraxinus excelsior L., Cornus mas L., Viburnum lantana L., Sorbus torminalis (L.) Krantz., Ligustrum vulgare L., Carex brizoides L., Campanula persicifolia L., Melissa transsilvanica Schur., Festuca sulcata Hack. та іншими), які $є$ на невисоких вулканічних горах, що височать серед рівнини (Юліївські гори), де займають південні сонячні схили.

Флороценосвіта букової рослинності (Fagetophytum) представлена фрагментарно (північні схили Чорної гори, Юліївські гори) і нараховує 74 (6,12\%) ценоелементи. У іï складі трапляються такі тіньолюбні види: Fagus sylvatica L., Dentaria bulbifera L., D. glandulosa Waldst. Et Kit., Galium odoratum (L.) Moench, Crocus heuffelianus Herb. Polygonatum verticillatum (L.) All., Lunaria rediviva L., Platanthera chlorantha (Cust.) Reichb., Millium effusum L., Hedera helix L., Asarum europaeum L., Ranunculus lanuginosus L., Circaea lutetiana L., Mercurialis perennis L., Brachypodium sylvaticum (Huds.) Beauv., Carex sylvatica Huds. та інші.

Флороценотип лучної рослинності (Pratophyton) нараховує 220 ценоелементів, що складає $18,2 \%$ від загальної кількості видів. На території Закарпатської області у середині минулого століття лучна рослинність займала значні території, однак під впливом господарської діяльності та проведення меліоративних робіт їх площа значно скоротилася. За гідрологічним режимом грунтів та приуроченістю до різних ділянок рельєфу луки Закарпатської рівнини віднесені Г. І. Біликом [1] до суходільних та заплавних, а за походженням - до первинно-природних та вторинних.

Зважаючи на ценотичні зв'язки та екологічну приуроченість видів, у складі лучного флороценотичного комплексу виділено флороценосвіти: заплавнолучна (Humidopratophytum) та суходольнолучна (Mesopratophytum).

Заплавнолучна флороценосвіта (Humidopratophytum) нараховує 92 ценоелементи $(8,02 \%$ видового складу флори) і об'єднує види, які зростають на добре зволожених заплавних луках у розгалуженому руслі р. Тиси та іï приток. Флороценотичний комплекс заплавнолучної рослинності представлений такими видами: Agrostis canina L., Festuca rubra L., F.pratensis 
Huds., Alopecurus pratensis L., Poa palustre L., Leucanthemum vulgare Lam., Plantago lanceolata L., Trifolium arvense L., Vicia cracca L., Galium verum L., Betonica officinalis L., Nardus stricta L., Anthoxanthum odoratum L., Prunella vulgaris L., Leontodon autumnalis L., Deshampsia cespitosa (L.) Beauv., Potentilla reptans L., Taraxacum officinale Web. Et Wigg., Ranunculus acris L. та іншими.

Суходольнолучна флороценосвіта (Mesopratophytum) нараховує 132 ценоелементи (10,92\% від видового складу флори). Суходольні луки на території досліджуваного регіону становлять невеликі ділянки, оскільки більшість з них розорані і використовуються для сільськогосподарського виробництва. Найчастіше такі угруповання з переважанням в травостої Agrostis gigantea Roth, Vulpia myuros (L.) C. C. Gmel. До них домішуються Bromus secalinus L., Poa compressa L., Anthemis arvensis L., Polygonum aviculare L., Cichorium intibus L., Rumex acetosella L., Plantago lanceolata L. та інші.

Флороценотип лучно-степової рослинності (Prato-Stepophyton) нараховує 164 ценоелементи (13,56\% видового складу флори). Сюди належать угруповання з переважанням Festuca rupicola Heuff., Alopecurus pratensis L., Poa angustifolia L., Arrhenatherum elatius (L.) J. et K. Presl. Серед костричників спостерігається ціла гама переходів від остепнено-лучних угруповань, де участь костриці незначна, до справжнього степу, де костриця переважає. У цих виявлено степові та лучно-степові види, серед яких: Potentilla argentea L., Filipendula vulgaris Moench., Agrostis tenuis Sibth., Achillea millefolium L., A. pannonica Scheele, A. distans Walds. et Kit., Poa angustifolia L., Plantago lancaolata L., Veronica spicata L., Sedum acre L., Inula hirta L., Iris hungarica Walds. Et Kit., Anthemis subtinctoria Dobrocz., Verbascum lichnitis L., Trifolium ochroleucon Huds., Onosma arenaria L. та інші.

На кам'янистих схилах горбів та на залізничних насипах, серед суходольних сінокосів та пасовищ трапляються степові угруповання. Вони поширені на низьких вулканічних горах (схили Чорної гори, Берегівські, Юлієвські, Косинські та Мужієвські горби). Степова флора тут представлена такими видами: Anthericum ramosum L., Dorycnium herbaceum Vill., Chamaecytisus austriacus (L.) Link, Festuca rubra L., Inula hirta L., I.ensifolia L., Phleum phleoides (L.) Karst., Ph.ambiguum Ten., Asperula cynanchica L., Leopoldia comosa (L.) Parl., Trifolium ochroleucun Huds., Saxifraga bulbifera L., Anthemis subtinctoria Dobrocz., Festuca rupicola Heuff., Iris germanica L., Crepis pannonica (Jacq.) K. Koch та іншими.

Флороценоти ксерочагарникової рослинності (Xerothamnophyton) нараховують 32 ценоелементи (2,65\% від загальної кількості видів). У його основі - угруповання степових чагарників, що зростають на кам'янистих, добре прогрітих сонячною радіацією схилах. Найчастотніше вони представлені на ріолітових вулканічних підвищеннях, займаючи південні та західні схили невисоких гір. Це угруповання Prunus L., Rosa L., Cytisus L., серед яких виявлено також Stipa capillata L., Leopoldia comosa (L.) Parl., Iris germanica L. та інші.

Флороценотип болотної рослинності (Paludophyton) нараховує 31 ценоелемент (2,56\% від загальної кількості видів). У його складі види трав'янисто-осокових боліт: Juncus effusus L., Scirpus sylvaticus L., Caltha palustris L., Cirsium rivulare (Jacq.) Link, Drosera rotundifolia L., Carex pilosa Scop., C.caespitosa L., Eriophorum vaginatum L., Oxicoccus palustre Pers., Utricularia bremii Heer., Pinguicula vulgaris L. На території досліджуваного регіону болота представлені дуже слабо, хоча в минулому вони були дуже поширені. Болота поступовими переходами пов'язані з болотистими луками, які займають знижені місця рівнини та представлені угрупованнями 3 домінуванням Carex vulpina L., C. acuta Good., Gliceria maxima (C.Hartm.) Holub, G. fluitans (L.) R. Br., Scirpus sylvaticus L., Festuca pratensis Huds., Eriophorum polystachon L., Cirsium rivulare (Jacq.) Link, Deshampsia caespitosa (L.) Beauv, Molinia coreuleae (L.) Moench, Nardus stricta L. та інших. Найбільші площі болотисті луки займають на заплавах p. Латориці [13].

Флороценотип гігро-гідрофільної (прибережно-водної) рослинності (Hygro-Hydrophyton) нараховує 129 ценоелементів (10,67\% від видового складу флори). У складі флороценотипу виділяються прибережно-водна (Hygrophytum) та водна (Hygrophytum) флороценосвіти.

Флороценосвіта прибережно-водної рослинності (Hygrophytum) нараховує 79 ценоелементів (6,53\% від усієї кількості видів) і утворена угрупованнями за участю 
різноманітних видів роду Salix L., до яких домішуються Rumex conglomeratus Murr, Tussilago farfara L., Stellaria palustris Retz, Spergularia rubra (L.) J.PRESL, Atriplex nitans Schk., Polygonum hydropiper L., Elatine hungarica Moesz, Veronica beccabunga L., Scirpus sylvaticus L., S. radicans Schkuhr та інші.

Флороценосвіта водної рослинності (Hygrophytum) нараховує 50 ценоелементів $(4,13 \%$ від загальної кількості видів) і представлена Batrachium aquatice (L.) Dum., Nymphaea alba L., Nuphar luteum (L.) Sm., Sagittaria sagittifolia L., Hydrocharis morsus-ranae L., Elodea canadensis Michx., Lemna minor L., L. gibba L., Stratiotes aloides L., Alisma gramineum Lej. та іншими.

Флороценонотип синантропної рослинності (Synantropophyton) нараховує 285 ценоелементів $(23,57 \%$ від загальної кількості видів), що свідчить про наростання антропогенного пресу в досліджуваному регіоні. До складу синантропофітону входять флороценосвіти сегетальної (Segetalophytum) та рудеральної рослинності (Ruderalophytum).

Флороценосвіта сегетальної рослинності (Segetalophytum) представлена видами, що виявлені на землях, які регулярно обробляються, і нараховує 132 ценоелементи $(10,92 \%$ від загальної кількості видів). Сюди входять Cirsium arvense (L.) Scop., Centaurea cyanus L., Agropyron repens L., Convovulus arvense L., Agrostemma githago L., Chenopodium album L., Consolida paniculata (Host) Schur, Fumaria officinalis L., Amaranthus hybridus L., Eruca sativa Mill., Sinapis alba L., Brassica campestris L., Neslea paniculata (L.) Desv. та інші.

Флороценосвіта рудеральної рослинності (Ruderalophytum) представлена 153 ценоелементами $(12,65 \%$ від видового складу флори), що фіксуються на необроблюваних землях і є супутниками людської діяльності. Серед них Ballota nigra L., Leonurus cardiaca L., Conium maculatum L., Artemisia vulgaris L., Gypsophilla paniculata L., Amaranthus crispus (Lesp.et Thev) N. Terr, Chenopodium album L., Ch. hybridum L., Atriplex nitens Schk, Sisymbrium orientale L., Erysimum repandum L., Barbarea verna (Miller) Ascherson, Lepidium ruderale L. та інші.

\section{Висновки}

Результати проведеного аналізу еколого-ценотичної структури флори Закарпатської рівнини показали, що провідну роль у складі досліджуваної флори відіграють неморальнолісовий (з переважанням геліокверцетальної флороценосвіти), лучний (з переважанням суходільнолучної флороценосвіти) та лучно-степовий флороценотипи.

Результати розподілу видів за основними флороценотичними групами відображають особливості основних генетичних типів рослинності, кліматичних, едафічних умов та рельєфу досліджуваної території.

1. Білик Г. І. Брадіс Є. М., Гринь Ф. О. та ін. Лучна рослинність Притисенської низовини та гірськолісового поясу. Рослинність Закарпатської області. Київ: Видавництво Академії наук УРСР, 1954. C. 92-112.

2. Бучинський I. О., Волеваха М. М., Коржов В. О. Клімат Українських Карпат. Київ: Наукова думка, 1971. $172 \mathrm{c}$.

3. Вернандер Н. Б. и др. Почвы УССР. Харьков: Госсельхозиздат УССР, 1951. 314 с. Геоботанічне районування Української РСР. Київ: Наукова думка, 1977. 264 с.

4. Григора І. М., Соломаха В. А. Основи фітоценології. Київ: Фітосоціоцентр, 2000. 240 с.

5. Дідух Я. П., Шеляг-Сосонко Ю. Р. Геоботанічне районування України та суміжних територій. Укр. ботан. журн. 2003. Т. 60, № 1. С. 6-17.

6. Дубовик О. Н., К Клоков М. В., Краснова А. Н. Флористические историко-географические районы степной и лесостепной Украины. Ботан. журн., 1975. Т. 60, № 8. С. 1092-1107.

7. Заверуха Б. В. Флора Волыно-Подолии и ее генезис. Киев: Наукова думка, 1985. 192 с.

8. Камелин Р. В. Флорогенетический анализ естественной флоры горной Средней Азии. Ленинград: Наука, 1973. 355 с.

9. Ліси Закарпаття. Сучасний стан, використання та охорона / Федурця І. Ю. та ін. Ужгород, 1997. 53 с.

10. Пригара О. В. Систематична структура флори Закарпатської рівнини. Укр.ботан.журн., 1988. Т. 45, № 5. C. 26-29.

11. Природа Закарпатської області / під ред. К. І. Геренчука. Львів: Виша школа, 1981. 156 с. 
12. Фельбаба-Клушина Л. М. Сучасний стан, тенденції змін та шляхи збереження й відтворення біорізноманіття рослинного покриву Закарпатської низовини. Науковий вісник Ужгородського університету. Серія Біологія. Вип. 25, 2009. С. 71-88.

13. Цысь П. Н. Область Вулканических Карпат и межгорных котловин. Область Закарпатской равнины. Физико-географическое районирование Украинской ССР. Киев: Изд-во Киев. ун-та, 1968. С. 629-637.

14. Шеляг-Сосонко Ю. Р., Устименко П. М., Дубина Д. В. Синтаксономічна різноманітність лісової рослинності долини Тиси та її приток. Укр. ботан. журн. 2010. Т. 67, № 2. С. 187-198.

15. Mosyakin S., Fedoronchuk M. Vascular plants of Ukraine. A nomenclatural checklist. Kiev, 1999. 346 p.

\section{References}

1. Bilyk H. I. Luchna roslynnist' Prytysens'koi nyzovyny ta hirs'kolisovoho poiasu. Bradis Ie. M., Bilyk H. I., Hryn' F. O. ta in. Roslynnist' Zakarpats'koi oblasti. Kyiv: Vydavnytstvo Akademii nauk URSR, 1954. S. 92 112 (in Ukrainian).

2. Buchyns'kyy I. O., Volevakha M. M., Korzhov V. O. Klimat Ukrains'kykh Karpat. Kyiv: Naukova dumka, 1971. $172 \mathrm{~s}$ (in Ukrainian).

3. Vernander N. B. Pochvy USSR / Vernander N. B. i dr. Khar'kov: Gossel'khozizdat USSR, 1951. 314 s (in Russian).

4. Heobotanichne rayonuvannia Ukrains'koi RSR. Kyiv: Naukova dumka, 1977. $264 \mathrm{~s}$ (in Ukrainian).

5. Hryhora I. M., Solomakha V. A. Osnovy fitotsenolohii. Kyiv: Fitosotsiotsentr, 2000. $240 \mathrm{~s}$ (in Ukrainian).

6. Didukh Ya. P., Sheliah-Sosonko Yu. R. Heobotanichne rayonuvannia Ukrainy ta sumizhnykh terytoriy. Ukr. botan. zhurn. 2003. T. 60. No 1. S. 6-17 (in Ukrainian).

7. Dubovik O. N., Klokov M. V., Krasnova A. N. Floristicheskie istoriko-geograficheskie rayony stepnoy i lesostepnoy Ukrainy. Botan. zhurn., 1975. T. 60, No 8. S. 1092-1107 (in Russian).

8. Zaverukha B. V. Flora Volyno-Podolii i ee genezis. Kiev: Naukova dumka, 1985. $192 \mathrm{~s}$ (in Russian).

9. Kamelin R. V. Florogeneticheskiy analiz estestvennoy flory gornoy Sredney Azii. Leningrad: Nauka, 1973. 355 s (in Russian).

10. Lisy Zakarpattia. Suchasnyy stan, vykorystannia ta okhorona / Fedurtsia I. Yu. ta in. Uzhhorod, 1997. 53 s (in Ukrainian).

11. Pryhara O. V. Systematychna struktura flory Zakarpats'koi rivnyny. Ukr.botan.zhurn.,1988. T. 45, No 5. S. 26-29 (in Ukrainian).

12. Pryroda Zakarpats'koi oblasti / pid red. K. I. Herenchuka. L'viv: Vysha shkola, 1981. $156 \mathrm{~s}$ (in Ukrainian).

13. Fel'baba-Klushyna L. M. Suchasnyy stan, tendentsii zmin ta shliakhy zberezhennia y vidtvorennia bioriznomanittia roslynnoho pokryvu Zakarpats'koi nyzovyny. Naukovyy visnyk Uzhhorods'koho universytetu. Seriia Biolohiia. Vyp. 25, 2009. S. 71-88 (in Ukrainian).

14. Tsys' P. N. Oblast' Vulkanicheskikh Karpat i mezhgornykh kotlovin. Oblast' Zakarpatskoy ravniny. Fizikogeograficheskoe rayonirovanie Ukrainskoy SSR. Kiev: Izd-vo Kiev. un-ta, 1968. S. 629-637 (in Russian).

15. Sheliah-Sosonko Yu. R., Ustymenko P. M., Dubyna D. V. Syntaksonomichna riznomanitnist' lisovoi roslynnosti dolyny Tysy ta ii prytok. Ukr. botan. zhurn. 2010. T. 67, No 2. S. 187-198 (in Ukrainian).

16. Mosyakin S., Fedoronchuk M. Vascular plants of Ukraine. A nomenclatural checklist. Kiev, 1999. 346 p.

\section{O. V. Pryhara}

Uzhhorod National University, Ukraine

\section{ECOLOGICAL AND COENOTIC STRUCTURE OF FLORA OF THE TRANSCARPATHIAN PLAINS}

The Transcarpathian plain is the northeastern part of the large Middle Danube lowland in the Transcarpathian region. The length of the plain is $80-90 \mathrm{~km}$, the width is $22-23 \mathrm{~km}$, the height is $102-120 \mathrm{~m}$ asl. Within the Transcarpathian plain stands out the Berehiv hills, represented by single volcanic mountains of 300-500 m altitude (Black Mountain - $568 \mathrm{~m}$ asl, Shalanka - $372 \mathrm{~m}$ asl. and other).

The Transcarpathian plain is located mainly on the right bank of the Tisza River. Soil-forming rocks are mostly acidic. The climate of the Transcarpathian plain is humid, temperate and continental.

The spontaneous flora of the Transcarpathian plain consists of 1209 species of higher vascular plants. Depending on the ecological and coenotic affiliation of flora species to the main zonal vegetation types, seven florencoenotypes were identified in the territory of the studied region: 1) Immoral (Nemoralophyton) - 375 coenoelements (33.33\% of the total number of species). In the composition of the Nemoralophyton the florencoenosvites are distinguished: a) oak-hornbeam 
(Querceto-carpinetophytum) - 130 coenoelements (10.75\%); b) helio-quercetal (Quercetophytum) 171 coenoelements $(14.14 \%)$; c) fagetal (Fagetophytum) - 74 coenoelements $(6.12 \%)$; 2) Meadow (Pratophyton) - 220 coenoelements (18.2\%). As a part of the Pratophyton the florencoenosvites are: a) flood-meadow (Humidopratophytum) - 92 coenoelements (8.02\%); b) land-meadow (Mesopratophytum) - 132 coenoelements (10.92\%); 3) Meadow-steppe (Prato-Steppophyton) - 164 coenoelements (13.56\%); 4) Xerothermic shrub (Xerothamnophyton) - 32 coenoelements $(2.65 \%)$; 5) Marsh (Paludophyton) - 31 coenoelements (2.56\%); 6) Hygro-hydrophilic (Hyhro-Hydrophyton) 129 coenoelements (10.67\%). As a part of the Hygro-Hydrophyton the florencoenosvites are: a) coastal-water (Hygrophytum) - 79 coenoelements (6.53\%); b) aqueous (Hygrophytum) - 50 coenoelements (4.13\%); 7) Synanthropic (Synantropophyton) - 285 coenoelements (23.57\%). In the composition of the Syntantropophyton the florencenosvites are as follows: a) vegetative vegetation (Segetalophytum) - 132 coenoelements $(10.92 \%)$ and b) ruderal vegetation (Ruderalophytum) - 153 coenoelements $(12.65 \%)$.

The results of the analysis of the ecological-coenotic structure of the flora of the Transcarpathian plain showed that the leading position is occupied by species of the immoral florenceonotype (Nemoralophyton) (with the predominance of the helio-quercetal florencoenosvita (Quercetophytum); meadow (Pratophyton) (with the predominance of land-meadow florencoenosvita (Mesopratophytum) and meadow-steppe (Prato-Steppophyton) florencoenotypes.

The distribution of species by major ecological-coenotic groups reflect the features of the main genetic types of vegetation, climatic, edaphic conditions and terrain of the territory under study.

Key words: Transcarpathian plain, flora, coenoelement, florencoenotype, florencoenosvita.

Надійшла 22.08.2019. 